\title{
KEPUSTAKAAN ILMU TRADISIONAL: SUMBANGAN NASKHAH-NASKHAH ILMU BEDIL MELAYU
}

\author{
Wan Mohd Dasuki Wan Hasbullah
}

\begin{abstract}
A bstrak
Di Malaysia, genre kepustakaan ilmu tradisional Melayu secara relatifnya boleh dikatakan baharu, selepas ia diperkenalkan oleh Harun Mat Piah pada dekad terakhir kurun ke-20. Genre yang diguna pakai dalam menelaah bidang kesusasteraan tradisional ini mempertegaskan tentang konsep ilmu orang Melayu yang terkandung di dalam naskhah-naskhah mereka, sebagai suatu korpus karya yang bersifat ilmu pengetahuan dan juga pedoman (treatise) yang mengandungi kepercayaan dalam konteks pengamalan ilmu-ilmu tersebut. Salah satu cabang karya kepustakaan ilmu tradisional yang dirujuk adalah ilmu yang berkait dengan penggunaan senjata api atau dinamakan sebagai ilmu bedil. Kalau hendak dibandingkan dengan naskhah-naskhah ilmu yang lain, setakat ini naskhah ilmu bedil masih terlalu kecil liputannya. Justeru, kertas kerja ini akan memperkatakan beberapa hal berkenaan naskhah ilmu bedil Melayu dan potensinya dalam memperkayakan konsep dan konteks kepustakaan ilmu tradisional.
\end{abstract}

Katakunci. IImu bedil, epistemologi, kepustakaan ilmu tradisional, naskhah Melayu.

\section{Kepustakaan IImu yang Tradisional?}

Di Malaysia, sebahagian besar daripada khazanah kepustakaan ilmu orang tua-tua pada masa dahulu masih banyak wujud dalam bentuk naskhah. Hanya sebahagian kecil sahaja daripadanya yang telah berhasil menjadi teks yang diterbitkan atau sekurang-kurangnya pernah dibicarakan dalam seminar-seminar ilmiah. Hal yang demikian disebabkan barangkali masih kurang pihak pengkaji yang sanggup mengerjakannya. Jika ada, dana yang didapati pula agak kurang, kerana tidak ramai pihak berkenaan yang menyedari (malah ragu-ragu pula) akan potensi dan kepentingan hasil-hasil kepustakaan ini pada zaman android sekarang. Justeru, pendedahan maklumat mengenai kepustakaan ilmu yang bersifat tradisional, masih belum meluas diketahui oleh masyarakat umum, meskipun suatu seminar khusus tentang kepustakaan ilmu tradisional orang Melayu telah julung kali diadakan pada tahun 2000. Dalam seminar tersebut, Dewan Bahasa dan Pustaka sebagai penganjur mengambil inisiatif membincangkan bidang ini dengan tujuan untuk melihat prospek kandungan dan ruang lingkup pembicaraannya 
menerusi naskhah Melayu secara lebih khusus dan mendalam (Harun 2005a:ix). Selain itu, Perpustakaan N egara Malaysia juga mengambil pendekatan sama untuk memantapkan lagi perbincangan mengenai karya kepustakaan ilmu tradisional, melalui penganjuran persidangan antarabangsa baru-baru ini yang banyak berfokus kepada ilmu dalam naskhah M elayu. ${ }^{1}$

A pakah sebenarnya kepustakaan ilmu tradisional? Dikatakan bahawa istilah 'kepustakaan' itu sendiri berasal daripada perkataan 'pustaka' yang bermaksud buku, kitab, atau secara arkaiknya kitab ramalan (pestaka). ${ }^{2}$ Jika itulah dasar pengertian yang diberikan, maka istilah kepustakaan boleh dimaknai sebagai sesuatu sumber bahan bertul is yang menjadi tempat rujukan bagi perkara-perkara tertentu, yang selalunya berbentuk informasi atau bersifat ilmu pengetahuan. Di samping itu, istilah kepustakaan juga dikaitkan dengan makna korpus atau himpunan - sesuatu persuratan atau hasil penulisan - di mana ia secara khusus merujuk kepada medium penyuratan sesuatu bidang ilmu pengetahuan. Dalam hal ini, sifat ilmu pengetahuan diletakkan dalam makna 'tradisional' dan 'lokal', sesuai dengan ciri-ciri keberadaannya sebagai khazanah warisan yang tersimpan dalam naskhah lama, kuno, arkaik, dan entah pelbagai macam istilah lagi. Oleh itu, kepustakaan ilmu tradisional secara jelas dapat difahamkan sebagai cerminan karya yang disampaikan dalam bentuk naskhah - di mana ia menyimpan pelbagai jenis ilmu pengetahuan yang bersifat tradisional dan lokal. Ada dua konsep utama yang digunakan bagi mentakrif teks kepustakaan ilmu tradisional secara operasional, iaitu konsep 'kepustakaan' sebagai sumber himpunan teks bertulis yang wujud dalam bentuk naskhah (M elayu), dan konsep 'ilmu tradisional', iaitu ilmu pengetahuan tempatan yang wujud dalam teks-teks berkaitan menurut lingkungan budaya masyarakat tertentu pada tahap tradisional.

Harun (2006) yang merupakan antara sarjana yang terawal yang mempelopori konsep dan pengkajian ke atas bahan-bahan teks seumpamanya dalam bidang kesusasteraan Melayu tradisional, turut mengistilahkan ia sebagai sastera sains dan teknologi tradisional atau epistemologi tradisional. Hal ini kerana konsep dan pembawaan ilmu pengetahuan dalam naskhah-naskhah tersebut cukup meluas dan serius. Dalam bidang kesusasteraan M elayu tradisional, khazanah tekskepustakaan ini merupakan sal ah satu genreyang menjuruskepada perbincangan mengenai ilmu tempatan yang menjadi bahan pembelajaran dan pengamalan sesebuah kelompok budaya dalam tempoh wujudnya teks naskhah berkenaan (Harun et al. 2006). IImu pengetahuan yang dikemukakan dalam teks-teksnya memperlihatkan tradisi dan identiti budaya tempatan dengan pemakaian bahasa dan idiom yang tersendiri. la berperanan menonjolkan sifat sesebuah kebudayaan menurut ciri-ciri khusus dari segi wacana teksnya, termasuk elemen-elemen naratif dalam penyampaian teks

1 Hal ini merujuk kepada Persidangan A ntarabangsa M anuskrip M elayu yang telah diadakan di Hotel Seri Pacific, Kuala Lumpur pada 6-7 Mei 2014. Dalam persidangan itu, banyak kertas kerja yang disampaikan oleh para pembentang memperihalkan serba-serbi ilmu yang terkandung dalam naskhah M elayu, termasuk juga dari aspek ilmu pengetahuan tradisional.

2 Perkataan ini dikatakan berasal daripada bahasa Sanskrit. la dikonotasikan dengan pengertian magis - dalam makna ramalan atau panduan (divinasi), atau sebagai sumber bertulis mengenai ramalan atau panduan itu (Wilkinson 1901:895). Kepustakaan disebutkan juga sebagai 'kesusasteraan', di mana ia dimaksudkan dengan sesuatu hasil persuratan (Kamus D ewan 2002:1076). 
yang ditulis dengan bahasa yang unik, serta diselitkan dengan contoh dan cerita yang menarik (Harun et al. 2006).

Termasuk ke dalam pengertian itu juga, Harun et al. (2006) turut berpendapat bahawa kepustakaan ilmu tradisional merupakan suatu khazanah kesusasteraan Melayu lama yang tiada beza dari segi nilai sasteranya; jika hendak dibandingkan dengan genre sastera tradisional yang lain, termasuk dalam aspek gaya bahasa, idiom, serta estetika. la memperlihatkan ciri-ciri kesusasteraan yang indah dan sesuai dengan kelaziman yang diterima pakai pada waktu karya itu wujud dan disebarkan. Malah menerusi beberapa kes, bahasa Melayu yang digunakan juga menurutnya, dilihat lebih indah dan tersusun. Keadaan yang demikian memperjelaskan kemampuan kebahasaan orang Melayu pada suatu masa lampau yang secara estetikanya berupaya membincangkan persoalan ilmu pengetahuan, di samping memanfaatkan istilah-istilah teknikal yang lebih khusus (Harun et al. 2006).

\section{Penjenisan Kepustakaan IImu Tradisional}

Teks-teks kepustakaan ilmu tradisional merupakan ekspresi gagasan kepercayaan yang dipraktikkan oleh orang Melayu pada era yang semasa dengan kelahiran karya-karya berkaitan. Selaras dengan pengalaman mereka, pelbagai jenis ilmu pengetahuan yang terkandung dalam teks-teks tersebut sudah lama dimiliki dan dimanfaatkan untuk faedah kehidupan seharian. Dengan pelbagai koleksi dan ruang lingkup pembicaraan, khazanah kepustakaan ilmu tradisional terdiri daripada sejumlah teks dan naskhah yang cukup besar. Namun begitu ruang epistemologi tradisional ini menurut Harun (2005a), tidak termasuk ilmu-ilmu yang bersifat formal seperti ilmu astronomi, perundangan, keagamaan, falsafah, metafizik, dan seumpamanya. Sesuai dengan konsepnya, kepustakaan ilmu tradisional merujuk pada tradisi pemikiran orang Melayu yang lebih bernuansa lokal sehingga secara tidak langsung menyerlahkan pula kearifan masyarakatnya (Harun et al. 2006). Dalam kes ini, ia bukan bererti menafikan tradisi penulisan karya-karya kepustakaan yang sebahagiannya memang berdasarkan akumulasi, penterjemahan, dan juga penafsiran sumber-sumber teks asing. Sebaliknya tradisi tempatan dilihat sebagai lebih menyerlah sesuai dengan konteks pengamalan dan praktikaliti khalayaknya pada waktu itu.

Teks-teks kepustakaan ilmu tradisional dapat diketahui dan dikenali dengan melihat judul naskhah itu sendiri. Hal ini dapat diperhatikan misal nya menerusi judul 'ilmu', di samping beberapakal imatseperti 'doa', 'azimat' , dan 'petua'. Namun unsur yang pal ing jelas memperlihatkan struktur atau bentuk ilmu pengetahuannya adalah tentu sekali dari segi isi kandungan teks naskhah. Antara jenis-jenis ilmu pengetahuan tradisional Melayu yang dikelompokkan menerusi kepustakaan ilmu tradisional sehingga kini adalah (lihat Harun et al. 2006, Harun 2014):

- ilmu bintang

- ilmu penujuman

- ilmu ramalan atau firasat 
- ilmu perubatan (dan perbomohan)

- ilmu bahasa (dan nahu)

- ilmu mengarang (termasuk terasul)

- ilmu hisab dan hitungan (dan konsep matematik)

- ilmu bedil

- ilmu pertanian (tanaman, ternakan)

- ilmu pertukangan (rumah, senjata tajam)

- ilmu berahi dan perkasihan (dan etika pergaulan suami isteri)

- ilmu kesenian (lakonan, tarian, nyanyian, rekreasi, dan pewayangan)

- serta beberapa ilmu lain seperti menyabung ayam.

Sesungguhnya memang amat luas dan pelbagai sekali ruang perbincangan yang terkandung di dalam teks-teks kepustakaan ilmu tradisional, apatah lagi jika ia ditanggapi sebagai sebahagian daripada khazanah kesusasteraan Melayu. Ia dibicarakan dalam ratusan naskhah yang tersimpan dalam pelbagai koleksi dunia kini. Dalam ratusan itu, tidak dinafikan bahawa sudah ada di antaranya yang telah dikaji, diterbit, didedahkan kepada umum serta diangkat sebagai khazanah warisan yang membanggakan seperti ilmu perubatan (kitab tib, mujarrobat), ilmu ramalan (ilmu nujum, raksi dan taabir mimpi), ilmu bahasa (tata bahasa, kosa kata) dan ilmu diplomatik (Harun 2014).

Biarpun begitu, hasil-hasil penulisan kepustakaan ilmu tradisional tidak pernah menjadi sandaran penting - hanya baru-baru ini sahaja minat terhadapnya semakin meningkat. Bahan-bahan naskhah yang bersifat ilmu dalam bidang pengajian teks kesusasteraan Melayu tradisional suatu ketika dahulu di Malaysia, mungkin lebih difahami misalnya dalam konteks sastera ketatanegaraan, atau keagamaan, begitu juga dengan undang-undang. Pada hal karya-karya yang menonjolkan ilmu pengetahuan tradisional dalam lingkungan kebudayaan sendiri kemungkinan tidak pernah diteliti langsung. Sebaliknya, ia banyak dipakai dalam bidang etnologi dan antropologi untuk mengkaji kebudayaan setempat, serta untuk meneroka tradisi ilmu pengetahuan masyarakat yang dijajah, seperti yang pernah dilakukan oleh Skeat (1984) atau Gimlette (1971) ketika mengkaji ilmu sihir dan ilmu perubatan Melayu. Dalam ruang pengkajian seperti itu, masalah tekstual dan filologikal secara metodologi tidak diendahkan sangat. Cukup jika ia hanya mampu dianggap sebagai sumber rujukan; justeru, tidak perlu perincian dari aspek kebahasaan dan kesusasteraannya kerana apa yang penting adalah fakta atau informasi yang diwakili oleh wacana teksnya.

Pada hujung abad ke-20, ada segelintir pengkaji tempatan yang berusaha menyelongkar ilmu pengetahuan tradisional dalam khazanah teks-teks berkenaan melalui pelbagai pendekatan. Kajian-kajian seumpamanya lebih bersifat rintisan menerusi penghasilan kertas kerja seminar dan terbitan artikel yang banyak berfokus kepada pendedahan teks atau perbincangan sesuatu ilmu pengetahuan

3 Dalam kes ini, Winstedt (1969) atau Liaw Yock Fang (1975) misalnya tidak pernah menjelaskan tentang teks kepustakaan ilmu tradisional atau sebarang naskhah yang bersifat ilmu tempatan. 
tradisional secara umum. ${ }^{4} \mathrm{H}$ asil-hasil penulisan tersebut selalu berlegar di sekitar persoalan bahasa, kesusasteraan dan kebudayaan. Dalam aspek kebudayaan pula, kepustakaan ilmu tradisional amat berperanan dalam menggambarkan kehidupan masyarakat lampau; iaitu dengan mengetengahkan falsafah ilmu, pemikiran, sudut pandangan dan cara hidup, seperti yang dapat dirujuk menerusi sejumlah artikel yang diselenggarakan oleh Rogayah dan Mariyam (2005).

Ternyata bahawa kegunaan teks-teks kepustakaan ilmu tradisional lebih terarah pada bidang kajian tentang budaya masyarakat (antropologi, psikologi budaya, termasuk etnografi), iaitu dengan menyuluh pandangan dunia dan sistem kepercayaan setempat menerusi ilmu perubatan, ramalan, firasat, seksologi, teknologi dan sebagainya (Mohd Taib 2005). Dengan erti kata mudah, teks-teks kepustakaan ini disedari sebagai medium penting dalam usaha untuk menganalis ilmu pengetahuan, pemikiran, dan kehidupan masyarakat pada masa lampau. Malah, ia merupakan sumber yang dapat memperjelaskan tentang nilai kecendekiaan masyarakat yang menguasai ilmu-ilmu tersebut, seperti yang pernah ditegaskan Haron (2009) menerusi sejumlah kajian yang turut didasarkan kepada karya-karya kepustakaan ilmu tradisional.

Sebagai sebuah genre yang membicarakan tentang ilmu pengetahuan masa silam, teks-teks kepustakaan ilmu tradisional turut mendapat perhatian dalam bidang sains. Termasuk dalam kajian seperti ini ialah beberapa kajian yang cuba dilakukan untuk meneliti konsep kesihatan dan ilmu farmakologi dalam naskhah ilmu perubatan M elayu melalui pendekatan falsafah sains. Kajian-kajian seperti ini yang kebanyakannya tidak menyentuh persoalan filologi, bertujuan untuk mencari asasteori sainsyang dikaitkan dengan epistemologi - misal nya perubatan tradisional - melalui penelitian terhadap model dan taksonomi teks naskhah yang dipancang oleh pandangan dunia orang Melayu. Sehingga kini, pengkajian tentang sains (atau disebut sebagai etno-sains Melayu) yang dihubungkan dengan pemikiran dan ilmu pengetahuan tradisional menerusi teks-teks kepustakaan ilmu tersebut terus diperkembangkan, misal nya oleh Shaharir, Mohd Alinor, Mat Rofa, dan ramai lagi rakan-rakan dari ASASI.5 Tulisan-tulisan mereka berkisar pada dapatan dan prinsip sains yang ditemui dalam teks-teks naskhah berkenaan. Sebahagian hasil tulisan itu boleh ditinjau misal nya menerusi selenggaraan Mohd Hazim (2009). ${ }^{6}$

\section{N askhah IImu Bedil dalam G enre Kepustakaan IImu Tradisional}

Berdasarkan keterangan yang telah dikemukakan, dapat disimpulkan bahawa

4 Lihat kertas-kertas kerja yang menghuraikan tentang ilmu-ilmu orang Melayu berdasarkan teks-teks kepustakaan ilmu tradisional, misal nya menerusi Seminar Kebangsaan Ethnobotani pada tahun 1991, Bengkel Kajian Naskhah M elayu: Kepustakaan IImu Tradisional tahun 2000, Bengkel Naskhah Kesultanan M elayu VI tahun 2005, Persidangan Antarabangsa Bahasa, Sastera dan Budaya Melayu tahun 2006, atau Seminar Antarabangsa M anuskrip Melayu tahun 2006, 2009, dan 2014. Terdapat juga siri seminar yang turut mendedahkan beberapa teks naskhah dalam genre ini, misalnya menerusi Seminar Bulanan N askhah Melayu yang dianjurkan oleh Jabatan Kesusasteraan A kademi Pengajian Melayu dan Jabatan Sejarah Fakulti Sastera dan Sains Sosial Universiti Malaya sejak tahun 2008. Namun begitu tidak dapat dinafikan bahawa terdapat kajian-kajian lain yang menggunakan teks-teks di luar genre ini seperti kajian Siti Zainon (1991) dan Umar Junus (2004) yang turut sama mengulas tentang ilmu pengetahuan dan pemikiran orang Melayu.

5 Atau A kademi Sains Islam M alaysia, lihat http:// www.kesturi.net/ .

6 Buat masa sekarang, Shaharir (2005) telah menunjukkan bahawa dalam karya kepustakaan ilmu tradisional Melayu, teks-teks sains dan teknologi jika dibandingkan teks-teks sejarah, sastera dan fal safah masih terlalu sedikit, iaitu $11 \%$ daripada keseluruhan naskhah yang terlibat (atau 647 daripada 5765 bahan naskhah yang diteliti oleh beliau). 
terdapat pelbagai jenis cabang ilmu pengetahuan orang Melayu yang dikenal pasti wujud dan tersimpan dalam karya-karya kepustakaan ilmu tradisional. Hal ini termasuk juga ilmu bedil. Naskhah ilmu bedil merupakan karya tulisan tempatan yang mengandungi ilmu pengetahuan berhubung kaedah menggunakan senjata api secara tradisional, atau dengan kata lain ilmu menembak. Ia mengandungi beberapa kaedah yang berkait dengan aspek pengendalian senjata api, seperti cara membuat peluru dan ubat bedil, begitu juga dengan cara mempersiapkan senjata api sebelum menggunakannya (Wan Mohd Dasuki 2013). Dalam kes ini, dipercayai bahawa orang Melayu mempunyai sumber teks yang khusus dan meluas mengenainya, sama seperti yang dapat dilihat pada kumpulan-kumpulan ilmu pengetahuan mereka yang lain, seperti kitab tib untuk ilmu perubatan, atau naskhah rejang untuk petua dan ilmu ramalan. Oleh kerana naskhah ilmu bedil lebih merupakan keterangan mengenai kaedah dan proses penggunaan senjata api, maka dalam konteks kepustakaan ilmu tradisional ini, ia boleh disifatkan sebagai suatu karya pedoman atau treatis (treatise).

Walau bagaimanapun, cabang ilmu bedil dalam karya kepustakaan ilmu tradisional Melayu merupakan antara himpunan ilmu pengetahuan tradisional orang Melayu yang dianggap kecil dan langka berbanding kebanyakan ilmu pengetahuan tradisional yang lain. Keadaan ini berlaku kerana tiada kajian ekstensif yang dilakukan pada naskhah ilmu bedil, tidak seperti naskhah-naskhah lain misalnya kitab tib. Harun, et al. (2006) ketika mengulas tentang ilmu bedil orang Melayu, terpaksa merujuk kepada penulisan Abdul Samad (1984) semata-mata kerana tidak ada sumber lain yang boleh dijadikan panduan. Tulisan yang berjudul Peluru Petunang itu merupakan satu-satunya hasil penerbitan naskhah kepustakaan ilmu tradisional orang Melayu berhubung ilmu menggunakan senjata api. Namun oleh kerana ia hanya berupa sajian teks tanpa sebarang analisis, konstruksi ilmu pengetahuan yang disampaikan agak sulit hendak difahami. Kekayaan teks ilmu bedil tidak benar-benar diserlah dan diperlihatkan kepentingannya. Justeru, sebagai kesinambungan terhadap kerja beliau dalam tiga dekad lalu, maka usaha untuk mengumpul, menyemak, mengalih huruf, merevisi, melengkapi, dan mempersembahkan himpunan teks naskhah ilmu bedil yang setakat ini diketahui wajar sekali dilakukan. Dengan demikian, eksplorasi Abdul Samad akan dapat diperdalamkan dengan menampilkan kembali naskhah-naskhah itu dalam bentuk yang baharu dari segi penurunan teks dengan interpretasi dan anotasi yang lebih lengkap dan jelas.?

\section{Kepustakaan IImu Tradisional, Naskhah IImu Bedil dan Potensi}

Pengkajian terhadap teks-teks naskhah ilmu bedil sejak beberapa tahun kebelakangan ini ternyata merupakan suatu pemerolehan maklumat studi yang boleh dikatakan relatif baharu. Tidak seperti teks-teks naskhah yang lain - rejang,

7 Salah satu usaha penting ke arah ini ialah dengan mengadakan kerjasama dengan Yayasan Karyawan di Malaysia, iaitu sebuah badan penerbit yang khusus dan progresif mengusahakan penerbitan naskhah-naskhah Melayu. Suatu edisi kritis yang lebih menyeluruh dan lengkap berkenaan naskhah-naskhah ilmu bedil Melayu telah dikerjakan - untuk memperkenalkan naskhah-naskhah tersebut kepada khalayak, di mana ia akan diterbitkan oleh Yayasan Karyawan tidak lama lagi dengan judul "IImu Bedil M elayu". 
ilmu bintang, firasat dan ramalan, begitu juga dengan kitab-kitab tib - yang kebanyakannya telah lama 'bermain' dalam budaya dan dunia Melayu, terus terang dapat dikatakan bahawa naskhah-naskhah itulah yang membentuk takrifan dan interpretasi pada konsep kepustakaan ilmu tradisional. Bagaimana pula dengan naskhah-naskhah ilmu bedil; apakah kepentingan dan potensi yang boleh diharapkan dalam hubungannya dengan konsep kepustakaan ilmu tradisional? Pertanyaan seperti ini bukan bermaksud hendak merombak pengertian yang sudah sedia difahami berkenaan konsep tersebut, tetapi sebaliknya naskhah ilmu bedil, sebagai antara bahan atau sumber naskhah yang baharu dicermati, barangkali dapat merejuvenasi pandangan yang membina (secara konseptual dan praktikal) terhadap konsep kepustakaan ilmu tradisional.

Sekurang-kurangnya ada tiga elemen utama yang mendekatkan naskhahnaskhah ilmu bedil dengan konsep yang telah dibincangkan - dalam usaha mencerahkan kembali pantulan kaca prisma yang terpancar sejak lebih sedekad itu. Tiga elemen tersebut adalah:

1. Ianggam treatis - naskhah ilmu bedil sebagai sumber maklumat peribumi yang penting tetapi kurang disedari sehingga ramai pihak yang tidak pernah menjangkaisi kandungan teksnya, diperlihatkan kewujudannyasebagai suatu teks sastera dalam langgam treatis yang versatil. Sifat versatil ini tercermin pada ciri tekstual naskhah serta hubungannya antara satu naskhah dengan naskhah yang lain. Dalam usaha mendekati dan memahami wacana tekstual secara mendalam, pemahaman terhadap ciri dan hubungan tekstual ini amat perlu kerana ia nanti memperlihatkan kesatuan representasi dan interpretasi pengalaman pemilik, penulis, atau penyalin naskhah tersebut terhadap konteks ilmu yang diwacanakan. Ciri dan hubungan tekstual itu membantu memperjelaskan watak dan warna kebudayaannya yang diperkirakan mempunyai autoriti ke atas representasi dan interpretasi pengalaman yang diungkap pada teks-teks itu.

Walau bagaimanapun, sesetengah pihak akan mendapati bahawa naskhah ilmu bedil setakat ini tidak berada dilandasan seperti yang dikemukakan oleh Zahir (2010). Dengan erti kata lain, ia tidak memiliki unsur yang lebih estetika berbanding teks-teks lain - misalnya kitab tib atau rejang, di mana ada di antara naskhahnya yang berbentuk syair dan gurindam. IImu bedil wujud dalam jalinan teks yang rigid, kerana ia merupakan kejelasan aturan dan prosedur konkrit berhubung aplikasi alatan material yang dipanggil senjata api dan ubat bedil. Bagi sesetengah pihak, hal itulah yang memadamkan unsur-unsur estetikanya (jika demikian, unsur estetika dalam naskhah ilmu bedil hanya wujud pada kata-kata mantera yang mengisi baris-baris jampi dan doa menggunakan senjata api). Justeru, dapat dikatakan bahawa beberapa segi pengertian sastera-kesusasteraan dalam konteks naskhah ilmu bedil seperti ini yang digolongkan ke dalam kepustakaan ilmu tradisional harus ditafsirkan dan diperjelas dengan lebih terperinci.

Berkaitan soal langgam inilah yang pernah menimbulkan kritikan oleh Zahir 
(2010) - bahawa sejauhmanakah sasteranya kepustakaan ilmu tradisional? Bagi Zahir, sesebuah karya sastera harus menunjukkan penghasilan kreatif dengan bahasa yang indah, dalam keinginan untuk menghibur dan memiliki nilai didaktik. Ia juga harus memiliki nilai-nilai estetika dari sudut bahasa, isi kandungan dan gaya persembahan. Menurut beliau, kepustakaan ilmu tradisional sukar untuk dikategorikan sebagai karya sastera atas alasan tiada seni sasteranya, meskipun ada elemen didaktik. Namun, suatu kes yang berbeza pulajikateksitu ditulisdalam bentuk syair, pantun ataupun gurindam yang menampakkan garapan bahasa yang indah. Namun pandangan itu ternyata tidak memberikan apa-apa bekas dalam menggetarkan konsep dan definisi kepustakaan ilmu tradisional dalam erti kata yang sesungguhnya. Dengan demikian, pengertian kepustakaan ilmu tradisional pada hari ini masih lagi dipersepsi menerusi warna kacamata yang tidak pernah berbeza sejak diprismakan lebih sedekad lalu.

2. Pengayaan istilah-istilah - khususnya yang bersifat teknikal akan yang mengkristalkan lagi kemampuan bahasa Melayu dalam mengungkapkan hal-hal, subjek-subjek, dan topik-topik yang bersifat operasional dan konkrit. Peristilahan teknikal seumpamanya amat jarang sekali diperhatikan dalam kes kajian-kajian teks kepustakaan ilmu tradisional. Pembinaan konsepkonsep baharu dan pentakrifan kembali pada jenis-jenis ilmu tradisional orang Melayu yang terkandung di dalam teks naskhah, dengan itu jauh sekali dicapai. Dalam pengkajian tentang matematik kabur dan aritmetik Melayu sebagai misalan, sejauhmana ia telah di bangun dan direkayasa untuk kegunaan praktis - walhal hambatan pembelajaran matematik bagi pelajar Melayu hari ini perlu ditangani sedapat mungkin. Berdasarkan misalan seperti itulah ditunjukkan bahawa perlunya aspek-aspek peristilahan ini diberikan fokus dalam pengkajian tentang kepustakaan ilmu orang Melayu.

Berbalik kepada naskhah ilmu bedil yang teks-teks rigidnya mengemukakan suatu sistem operasional tentang peralatan senjata api - amat sulit sekali - biarpun pada peringkat yang paling awal, iaitu dengan tujuan hendak memahami makna teks berkenaan. Sebagai contoh, payah sekali hendak memahami kaedah memasukkan atau memasang sumbu pada burung bedil bagi selaras istinggar, ataupun teknik hendak mendapatkan bidikan sasaran jika istilah teknikal itu tidak benar-benar difahami. Justeru, perkara inilah yang tertinggal dalam kajian-kajian mengenai ilmu yang terkandung dalam teks-teks kepustakaan tradisional Melayu - di mana ia perlu dibangun, diperinci dan diperkembangkan. Istilah-istilah teknikal dan khusus itu patut dilihat sebagai suatu potensi yang bukan sahaja mengangkat keupayaan bahasa Melayu sebagai bahasa ilmu (yang kalau ingin disebut saintifik di sini) bahkan aspek kearifan itu sendiri merupakan hal yang patut dipertahan dan direkayasa.

3. Pengayaan dan penegasan konsep ilmu serta pemikiran Melayu - dalam cara bagaimana hendak menangani sesuatu peralatan material. Konsep yang 
dicapai dan diketengahkan oleh naskhah-naskhah ilmu bedil seharusnya difahami secara berbeza. Aspek-aspek kearifan yang ditonjolkan perlu dilihat dalam kerangka epistemologi tradisional orang Melayu itu sendiri. Tradisi epistemologi Barat memperkenalkan manusia tentang empirisisme (alam real) dan rasionalisme (alam ideal), iaitu dua buah aliran yang saling bertentangan dalam menjelaskan tentang upaya manusia membentuk ilmu pengetahuan (A bdul Rahman 2010). Di sebalik perbezaan pandangan aliran empirisisme dan rasionalisme, perlu ditegaskan pula bahawa orang Melayu - yang merupakan sebahagian daripada bangsa Asia - menyusun kerangka epistemologi mereka menurut pola fikir holistik (Nisbett \& Norenzayan 2002). Daya kognitif yang bergerak secara holistik melahirkan makna atau konsepsi yang tidak bersifat dikotomi, menyebabkan tiadanya garis pemisah antara alam real (perlakuan fizikal) dengan alam ideal (fikiran). Sebaliknya ia mewujudkan gagasan harmoni antara alam real (ruang fizikal) yang berada di luar daripada bahagian diri individu dengan alam ideal (ruang bukan fizikal) yang dialami di dalam dirinya. Ketiadaan sifat ini menjadikan orang Melayu memahami pengalaman fizikal secara asosiatif dengan perhitungan yang berasaskan kepada sifat kesamaan dan saling berkait antara kedua-dua ruang ( $\mathrm{N}$ isbett et al. 2001). Berasaskan asosiatif dan kesamaan, pengalaman fizikal dipersepsi dan difahami menurut kematangan pertimbangan dari dalam, iaitu menerusi renungan hati atau intuisi. Intuisi yang berada pada ruang bukan fizikal (di dalam hati) menerbitkan kesedaran dengan merentasi keterbatasan alam fizikal sehingga berupaya memberikan pemahaman yang mendalam dan menyeluruh terhadap realiti kewujudan alamnya (Hashim 2001).

Dengan itu, timbullah bentuk-bentuk metafora dan pernyataan simbolik dalam memberikan tanggapan, renungan, dan abstraksi terhadap alam fizikal. Daya kognitif orang Melayu menyelaraskan abstraksi dan makna pada peringkat inferensi logik berdasarkan, atau dengan melibatkan sistem kepercayaan dan metafizik menurut pandangan dunia mereka sendiri (lihat N isbett \& N orenzayan 2002). Dengan erti kata mudah, kompleksiti pemikiran orang Melayu sehingga terstrukturnya landasan ilmu pengetahuan mereka adalah didasarkan kepada sistem kepercayaan. Dalam konteks ini juga, sama ada ilmu pengetahuan itu dicerap dan dibentuk menerusi pembelajaran, pemerhatian, pengalaman, mahupun penceritaan, sistem kepercayaan menjadi pancang yang menambat legitimasi ilmu pengetahuan sehingga benar-benar diyakini (Harun 2005b).

Kerangka epistemologi yang dipertegas dalam cara mereka itu membawa kepada pewujudan karekter teknikal yang tersendiri, di manaia menampilkan kelainan perspektif dalam aplikasi ilmu pengetahuan mereka. Ia merupakan tindak balas dinamik terhadap rangsangan unsur kebudayaan asing dalam usaha mengimbangi, mengekal, dan meneruskan nilai kebudayaan sendiri dalam cara yang khusus. Inilah potensi naskhah ilmu bedil yang patut dikira 
sebagai sumbangan yang diperlukan terhadap pembinaan data dal am kajiankajian mengenai ilmu pengetahuan orang Melayu zaman bahari. Oleh sebab 'kepustakaan' naskhah ilmu bedil tidak pernah dibangkitkan dalam kajiankajian terdahulu, segenap aspek seumpamanya (teknikal orang M elayu dalam aplikasi senjata api dan ubat bedil) tidak pernah diketahui dengan jelas. Hal ini merupakan sesuatu yang cukup dikesali, sedangkan naskhah-naskhah ilmu bedil berupaya melengkapkan body of knowledge teknologi bahari orang Melayu.

Inilah ketiga-tiga elemen perlu disorot dan dicermati (menurut pandangan kertas ini) dalam makna yang perlu difahami menurut cakupan kepustakaan ilmu orang Melayu - di mana teks-teksnya itu ditakrifkan dalam konteks lokal dan tradisional.

\section{Pengakhiran yang Belum Selesai}

Kepustakaan ilmu tradisional merupakan suatu konsep dasar yang digunakan dalam upaya untuk memahami teks-teks tradisi yang berada di luar lingkungan besar kesusasteraan tradisional M elayu. Bentuk dan penjenisan kesusasteraan untuk teks-teks seperti ini yang dibincangkan pertama kali sebagai sebuah karya sastera oleh Harun; merupakan sesuatu yang tidak pernah diutarakan sebelum ini (Zahir 2010). Teks-teks yang berada dalam penjenisan atau genre menurut konsep ini, merupakan kumpulan teks yang dianggap marginal. Hal ini kerana teks-teks yang bersifat ilmu dal am ruang lingkup pengajian teks kesusasteraan M elayu tradisional suatu ketika dahulu hanya melihat ataupun mengambil kira karya-karya undangundang, keagamaan, ketatanegaraan, atau yang seumpamanya, sementara karyakarya yang menonjolkan pengetahuan tradisional dalam lingkungan kebudayaan sendiri pula tidak pernah ditel iti dan dicermati. Wal au bagai manapun, karya-karya kepustakaan ilmu tradisional kini telah berjaya mencuri perhatian khalayak dan mendapat tempat dalam penyelidikan-penyelidikan ilmiah.

Justeru, usaha mengangkat karya-karya kepustakaan ilmu tradisional masih perlu diteruskan, memandangkan teks-teks naskhah dalam genre ini memiliki manfaat yang amat besar, bukan sahaja dalam bidang kesusasteraan itu sendiri bahkan dalam pelbagai bidang dan bentuk kajian mengenai pemikiran, kearifan dan ilmu pengetahuan tradisional orang M elayu. Sebagaimana yang dicadangkan dalam kertas ini bahawa, usaha mengangkat naskhah-naskhah berkaitan patut diikhtiarkan dengan cara melihat kembali dan merejuvenasi konsep kepustakaan ilmu tradisional M elayu - hal ini penting dalam usaha menangani teks-teks naskhah tersebut secara lebih komprehensif. Untuk itu juga, suatu kajian pemetaan naskhahnaskhah kepustakaan ilmu tradisional Melayu harus segera dilaksanakan.

\section{Rujukan}

A bdul Rahman A bdullah. 2010. Wacana Falsafah Sains: Sejarah dan Pemikiran. Pulau Pinang: ISDEV-Universiti Sains Malaysia.

A bdul Samad A hmad. 1984. Peluru Petunang. Kuala Lumpur: Dewan Bahasa dan 
Pustaka.

Gimlette,J.D. 1971. M alay Poisons and Charm Cures. KualaLumpur: Oxford University Press.

Haron Daud. 2009. Kitab IImu N ujum M elayu. Bangi: Institut Alam dan Tamadun Melayu, Universiti Kebangsaan Malaysia.

Harun Mat Piah. 2005a. Pengenalan. DIm. Rogayah A bdul Hamid \& Mariam Salim (ed.), Kepustakaan IImu Tradisional, vii-xv. Kuala Lumpur Dewan Bahasa dan Pustaka.

Harun Mat Piah. 2005b. Rejang sebagai sebahagian epistemologi Melayu. DIm. Rogayah A bdul Hamid \& Mariam Salim (ed.), Kepustakaan Ilmu Tradisional, 50-74. Kuala Lumpur: Dewan Bahasa dan Pustaka.

Harun Mat Piah. 2014. Ilmu perkasihan (seksologi) Melayu tradisional: Satu pembicaraan awal. Kertas kerja dibentangkan dalam Persidangan A ntarabangsa M anuskrip M elayu pada 6-7 Mei 2014 di Hotel Seri Pacific, Kuala Lumpur.

Harun MatPiah, et al. 2006. K esusasteraan M elayu Tradisional. Kuala Lumpur: Dewan Bahasa dan Pustaka.

Hashim Musa. 2001. Falsafah, Logik, Teori, N ilai dan Etika M elayu: Suatu Pengenalan. Kuala Lumpur: Akademi Pengajian Melayu.

Kamus D ewan. 2002. Edisi ketiga. Kuala Lumpur: Dewan Bahasa dan Pustaka.

Liaw Yock Fang. 1975. Sejarah Kesusasteraan M elayu Klasik. Singapura: Pustaka Nasional.

Mohd Hazim Shah Abdul Murad (ed.). 2009. Sains, Agama dan Budaya di Alam M elayu. Kuala Lumpur: Dewan Bahasa dan Pustaka.

Mohd Taib Osman. 2005. Kitab tib ubat-ubat Melayu. DIm. Rogayah A bdul Hamid \& Mariam Salim (ed.), Kepustakaan Ilmu Tradisional, 1-25. Kuala Lumpur: Dewan Bahasa dan Pustaka.

N isbett, R.E., \& Norenzayan, A. 2002. Culture and cognition. DIm. D.L. Medin \& $H$. Pashler (ed.), Stevens' $H$ andbook of Experimental Psychology, edisi 3, jilid 2: $M$ emory and Cognitive Processes, 561-597. New York: John Wiley and Sons.

N isbett, R.E., et al. 2001. Cultureand systems of thought. P sychological Review, 108(2): 291-310.

Rogayah A bdul Hamid \& Mariam Salim, (ed). 2005. Kepustakaan Ilmu Tradisional. Kuala Lumpur: Dewan Bahasa dan Pustaka.

Shaharir Mohamad Zain. 2005. Sains dan teknologi Melayu sebelum dikuasai penjajah dari Eropah. DIm. Rogayah A. Hamid \& Mariam Salim (ed.), Kepustakaan IImu Tradisional, 159-213. Kuala Lumpur: Dewan Bahasa dan Pustaka.

Siti Zainon Ismail. 1991. Konsep Pakaian Cara Melayu: Satu Kajian A nalisis Budaya Benda. Tesis Ph.D Jabatan Pengajian Melayu yang tidak diterbitkan, Fakulti Sastera dan Sains Sosial, Universiti Malaya Kuala Lumpur.

Skeat, W.W. 1984. M al ay M agic. Kuala Lumpur: Oxford University Press.

Umar Junus. 2004. Naskhah sebagai sumber ilmu pengetahuan. Jurnal Filologi M elayu 12: 63-76.

Wan Mohd Dasuki Wan Hasbullah. 2013. Pengetahuan dan Teknologi M elayu Berhubung Penggunaan Senjata A pi: A nalisis N askhah IImu Bedil. Disertasi sarjana Akademi Pengajian Melayu, Universiti Malaya, Kuala Lumpur.

Wilkinson, R.J. 1901. A M alay-English D ictionary, jilid 1 dan 2. Singapore: Kelly and Walsh Limited.

Winstedt, R.O. 1969. A H istory of Classical Liturature. New York: Oxford University Press.

Zahir Ahmad. 2010. Kecelaruan konsep dan bentuk (genre) dalam kesusasteraan Melayu: Satu perbincangan awal. DIm. Puteri Roslina Hj. Abd. Wahid, et al. (ed.), Cabaran Semasa Pengajian M elayu, 122-127. Kuala Lumpur: Akademi Pengajian Melayu. 